\title{
Facing Digital Realities: Where Media Do Not Mix
}

\author{
DAVID TRIPPETT
}

\begin{abstract}
Wagner's vaunted model of artistic synthesis persists in scholarly assessments of his work. But at its centre, the composer argued that the media of voice and orchestra do not mix: they retain their identities as separate channels of sound that can neither duplicate nor substitute for one another. Taking as a starting point Wagner's claims for the nonadaptability of media, this article addresses the adaptation of Wagner's music to the modern digital technologies of HD cinema and video game. Drawing on a wide circle of writers, from Schiller and Žižek to Bakhtin, Augé, Baudrillard and second-generation media theorists, it interrogates the concept of 'reality' within live acoustic performance, both historically, as a discursive concept, and technologically, via the sensory realism of digital simulcasting and telepresence. The philosophical opposition of appearance and reality fails when reality is defined by the intimate simulation of a sensory event as it is registered on the body. And by contrasting the traditions of high fidelity in (classical) sound recording with that of rendering sound in cinema, I suggest ways in which unmixable media appear to have an afterlife in modern technologies. This raises questions - in a post-Benjamin, post-McLuhan context about our definition of 'liveness', the concept of authenticity within mediatised and acoustic sounds, and our vulnerability to the technological effects of media.
\end{abstract}

Technologies are artificial, but ... artificiality is natural to humans.

(Walter Ong) ${ }^{1}$

\section{Wagner and Wirklichkeit}

The rhetoric of synthesis is hard to get away from in writings about Wagner. As a principle of logic, its force - derived in part from classical dialectics, a discursive mode - can be read and applied broadly. It has shaped discussion of artistic media, as per Jack Stein's interest in the all-pervasive infinity of the Gesamtkunstwerk, ${ }^{2}$ and of sexual difference, as per Jean-Jacques Nattiez's critique of telescoped gender as an aesthetic platform. ${ }^{3}$ It has been applied to metaphysics, as per Bryan Magee's reading of Schopenhauer as the lynchpin for Wagner's music-theatre-philosophy triumvirate. ${ }^{4}$ And it underpins Adorno's reading of Wagnerian sonority as a concealment (or synthetic unification) of the division of mental and physical labour in the composer's orchestration, aligning it with the commodity: 'sound from which the traces of its production have been removed'.

I am most grateful to Justin Williams for offering thoughts on an earlier version of this article.

Walter Ong, Orality and Literacy: The Technologizing of the World (London, 1982), 83.

Jack Stein, Richard Wagner \& the Synthesis of the Arts (Westport, CT, 1960).

Jean-Jacques Nattiez, Wagner Androgyne: A Study in Interpretation (Princeton, 1993).

Bryan Magee, Wagner and Philosophy (London, 2000), $193 \mathrm{ff}$.

5 Theodor W. Adorno, In Search of Wagner, trans. Rodney Livingstone (London and New York, 2005), 72. 
If these critiques derive part of their appeal from mimicking the very process of synthesis that forms their object, Wagner's comments in Oper und Drama (1851) on the media-specific properties of the voice may give us pause. At the centre of a musico-poetic fusion in the Gesamtkunstwerk he argues that media do not mix, asserting: 'the complete difference in the purely sensuous utterance of the orchestra from the equally purely sensuous utterance of the vocal sound mass'. ${ }^{6}$ Failure to accept this, we learn, accounts for 'a large part of the ineffectiveness of our approach to operatic melody until now. ${ }^{7}$ On the one hand, a singer's orchestral harmonic accompaniment should not leave out pitches occurring in the vocal line from its otherwise self-contained chords. The timbres of voice and instrument are so distinct that we would only hear incomplete harmony:

We immediately become aware that the harmony is simply incomplete, and the melody had not thereby been harmonically supported [gerechtfertigt; precisely because our ear, detecting the great distinction between the sensuous timbre of instruments and that of the human voice, instinctively separates the one from the other, and thus receives the mere impression of two diverse elements: a melody inadequately supported [gerechffertigt] by its harmony; and a harmonic accompaniment full of gaps. ${ }^{8}$

On the other hand, nor should vocal melody be duplicated in the orchestra, given the unique character of the voice, for this asserts the melody's purely instrumental identity, resulting only in a monstrous doubling: 'the human voice's delivery of the melody ... [becomes] utterly superfluous and like a second, disfiguring head unnaturally planted on [the body of instruments'] shoulders'. 'The ready counter-examples before and after 1851 that ignore Wagner's precepts, making effect out of precisely what he prohibits, only serve to underscore the idiosyncrasy of the composer's perspective on discrete media channels and clarity of communication at mid-century.

For Wagner, then, media do not mix to the extent that their functions remain separate in his imagination. There can be no equivalence between the channels of sound defined metonymically as text and timbre, and so the metaphor of the mixing desk, so keenly anticipated by Baudelaire and Liszt's commentaries on graded blending of instrumental sonorities in the Prelude to Lohengrin (1848), must fail at the point of the Herald's first

6 'die vollkommene Unterschiedenheit des Orchesters in seiner rein sinnlichen Kundgebung von der ebenfalls rein sinnlichen Kundgebung der Vokaltonmasse'. Richard Wagner: Samtliche Schriften und Dichtungen, 16 vols. (Leipzig, 1911-14), 4: 166. Cf. Richard Wagner's Prose Works, trans. W. Ashton Ellis, 8 vols., rpt. (Lincoln and London, 1995), 2: 309. (Oper und Drama)

7 'Diese ungemein wichtige ... Wahrnehmung vermag uns über einen großen Teil der Unwirksamkeit unsrer bisherigen Opernmelodik aufzuklären.' SSD 4: 168. Cf. PW 2: 310.

(Oper und Drama)

8 'So werden wir augenblicklich gewahr, daß die Harmonie eben unvollständig, und die Melodie dadurch eben nicht vollständig harmonich gerechtfertigt ist, weil unser Gehör die menschliche Stimme, in ihrer großen Unterschiedenheit von der sinnlichen Klangfarbe der Instrumente, unwillkürlich von diesen getrennt wahrnimmt, und somit nur zwei verschiedene Momente, eine harmonisch unvollständig gerechtfertigte Melodie, und die lückenhaft harmonische Begleitung, zugeführt erhält.' SSD 4: 168. Cf. PW 2: 310. (Oper und Drama)

9 'Die Gesamgstimme erschien im Vortrag der Melodie auf diesem harmonisch und melodisch vollständig abgeschlossenen Tonkörper im Grunde durchaus überflüssig und als ein zweiter, entstellender Kopf ihm unnatürlich aufgesetzt.' SSD 4: 169. Cf. PW 2: 311. (Oper und Drama) 
word 'Hört!' (Hear ye!) in Act I. ${ }^{10}$ A synthesis of vocal-instrumental timbres obscures text (and hence the music's only discernible 'poetic aim'), becoming incongruous with the grit of pragmatism embedded in what is so often taken to be Wagner's idealist synthesis. ${ }^{11}$ 'Weia! Waga!' - the next words that would follow an instrumental Prelude of iconic sonority - would simply accept their incomprehensibility: phonemes without signifiers, that is, quite literally a 'purely sensuous utterance'.

Taking as a starting point Wagner's claims for the non-adaptability of media, I shall focus on the adaptation of Wagner's music to modern digital technologies. If these forms of adaption are not innocently comparable, they nevertheless establish a discursive platform from which to critique the media through which we increasingly access opera today. Half a century has passed since Marshall McLuhan formulated the medium as the 'message', wherein the physical form of a medium is intrinsic to any putative content (or 'message') it conveys because of the mode of sensory perception it elicits. Accepting this, it follows that media, in driving changes in 'the scale and form of human association and action', become the antithesis of transparent reproducing or transmitting devices. Indeed, a renewed public interest in McLuhan's writings during the internet age rests partly on the acceptance of a manifest 'danger' that he (after Walter Benjamin) ${ }^{12}$ cautioned against, namely our vulnerability to the technological effects of media, which: 'do not occur at the level of opinions or concepts, but alter sense ratios or patterns of perception steadily and without any resistance'. ${ }^{13}$ Recent academics from Nicholas Carr and Andy Clark

10 See Charles Baudelaire, Selected Writings on Art and Literature, trans. P.E. Charvet (London, 1972), 329-32. Baudelaire quotes Liszt's essay on Lohengrin in its original French (pp. 329-30). Liszt's essay had a complex publication history; full details are given in the excellent commentary by Gerhard Winkler and Rainer Kleinertz to volume 4 of Liszt's complete writings. See Liszt, Sämtliche Schriften, 9 vols. [projected], gen. ed. Detlef Altenburg (Wiesbaden, 1989-), 4, 211-33.

11 Christopher Morris's useful summary of the idealist traditions of cohesion among the arts reminds us that Wagner's Gesamtkunstwerk was nourished on a long-standing impulse to unify media, making Wagner's retention of separate media all the more striking; see "Too Much Music": The Media of Opera', in The Cambridge Companion to Opera Studies, ed. Nicholas Till (Cambridge, 2012), esp. 103-5. Wagner's stance finds sympathy with the Modernist film director Dziga Vertov in We. A Version of a Manifesto (1922), wherein he indefinitely deferred the utopia of synthesis to allow time to explore the integrity of individual new media: 'We protest against the mixing of the arts that many call synthesis. The mixing of bad paints, even those ideally suited to the colours of the spectrum, produces not white but dirt. / We are for a synthesis at the zenith of achievement of every art form - but not before'. In Richard Taylor and Ian Christie (eds.), The Film Factory: Russian and Soviet Cinema in Documents, 1896-1939 (Abingdon, 1994), 69-72, at 69.

12 Walter Benjamin argued back in 1938 that 'technology subjugated the human senses to a complex kind of training', coining the term Anschanungsansicht for instruction in perception and intuition that our senses undergo through exposure to media. See Benjamin, Selected Writings, Volume 4: 1938-40 (Cambridge, MA, 2003), 328.

13 Marshall McLuhan, Understanding Media: The Extensions of Man (Cambridge, MA, 1994), 9, 18. Examples of press coverage that asserts a public awareness of the relevance of his ideas in the new millennium would include: Alexander Stille, 'Marshall McLuhan is Back From the Dustbin of History', New York Times (14 October 2000), www.nytimes.com/2000/10/14/arts/marshallmcluhan-back-dustbin-history-with-internet-his-ideas-again-seem-ahead.html (accessed 2 October 2013); and Nigel Beale, 'Living in Marshall McLuhan's Galaxy', The Guardian (28 February 2008), www.theguardian.com/books/booksblog/2008/feb/28/livinginmarshallmcluhansga (accessed 2 October 2013). 
(focusing on new patterns of cognition) to Katherine Hayles (focusing on the embodiment of new technologies) have contributed book-length studies to an emerging Anglophone literary genre on the transformative power of digital media. ${ }^{14}$ Hayles's affirmative position is representative:

The more one works with digital technologies, the more the keyboard comes to seem an extension of one's thoughts rather than an external device on which one types. Embodiment then takes the form of extended cognition, in which human agency and thought are enmeshed within larger networks that extend beyond the desktop computer into the environment. ${ }^{15}$

In this context, it would seem verging on doublethink to celebrate the exponential growth in opera's dissemination through digital media of the last decade without at the same time asking what profound changes it has brought about. Innovation in the technological means of reproduction and dissemination of performance today ostensibly conceals the quality of difference to a work's originary form that is so openly manifest in instrumental arrangements, from Louis Brassin's Magic Fire-Scene to Hans Werner Henze's Richard Wagnersche Klavierlieder (aka Wesendonck Lieder), a tradition Wagner readily contributed to and into which his own music was absorbed from 1849 . In other words, the media broadcast, like the arrangement, becomes equally supplementary as a 'necessarily indefinite process' beyond what is given as the identity of a work. ${ }^{16}$

Since the digital turn of the early 1980s, the recording industry has been susceptible to ever more freely migrating content - between both formats and devices. While this has generated significant debate over intellectual property and the future of revenue streams from the newly dominant business model of on-demand streaming, questions of what aesthetic and musicological sensibilities are at stake in digitally reproducing live or recorded opera are less developed. ${ }^{17}$ Wagner's works are, in this sense, only a case study for modern opera media aesthetics, and it is worth clarifying that the intuitive connection here with discursive genealogies (Wagner to Virtual Reality or Bayreuth to Cyberspace would be two examples) ${ }^{18}$ are incidental rather than intrinsic to this enquiry.

14

Nicholas Carr, The Shallows: What the Internet is Doing to our Brain (New York, 2010); Andy Clark, Natural-Born Cyborgs: Minds, Technologies, and the Future of Human Intelligence (New York, 2004); and Katherine Hayles, How We Think: Digital Media and Contemporary Technogenesis (Chicago, 2012).

15 Hayles, How We Think, 3.

16 Jacques Derrida, Of Grammatology, trans. Gayatri Chakravorty Spivak (Baltimore, 1998), 281.

17 In contrast, the related scholarly literature on the relation of opera to film, and opera's shadowy afterlife in the mechanisms of film aesthetics is rich. A sampling of recent contribution would include Christopher Morris, 'Wagner Video', Opera Quarterly 27 (2011), 235-55; Marcia J. Citron, When Opera Meets Film (Cambridge, 2010); Michal Grover-Friedlander, Vocal Apparitions: The Attraction of Cinema to Opera (Princeton, 2005); Carolyn Abbate, 'Wagner, Cinema, and Redemptive Glee', Opera Quarterly 21 (2005), 597-611; Ken Wlaschin (ed.), Encyclopedia of Opera on Screen: A Guide to More than 100 Years of Opera Films, Videos, and DVDs (New Haven, 2004); David P. Schroeder, Cinema's Illusions, Opera's Allure: The Operatic Impulse in film (New York, 2002); and Jeongwon Joe and Rose Theresa (eds.), Between Opera and Cinema (New York, 2002).

18 See Randall Packer and Ken Jordan, Multimedia: From Wagner to Virtual Reality (New York and London, 2001); and Matthew Wilson Smith, The Total Work of Art: From Bayreuth to Cyberspace (New York, 2007). 
All stage performance cradles a notion of 'reality'. ${ }^{19}$ And a basic premise of opera, one that links Wagner's critique of musical media to their digital afterlife, is the assumption that an acoustic performance is the 'reality' of that performance event, hierarchically prior to mediatised versions of the same. The reality of sound and vision in a theatre is rarely mentioned as such by Wagner (unsurprising, perhaps, in a pre-Edison era). In contrast to the negative term 'realism' (Realismus), the noun 'Wirklichkeit' appears frequently in his writings; it forms the antipode to Vorstellung idea, representation, imagination, perception - and is typically aligned with a physical manifestation that is brutal as well as tangible. That the most representative historical people for the concept - in Wagner's creative historical memory - are the Romans is indicative of his opinion that the concept of reality is blind and base when unguided by the creative imagination:

These brutal conquerors of the world were suited only to wallow in the most absolute reality [in der positivsten Realität; their powers of imagination could be satisfied only in the most material fulfilment. Their philosophers they gladly left to flee shuddering from public life to abstract speculations; but, for themselves, they loved to revel in the most concrete and open bloodthirstiness, beholding human suffering set before them in absolute physical reality [in absoluter physischer Wirklichkeit]. ${ }^{20}$

Jacob and Wilhelm Grimm's Deutsche Wörterbuch, whose first fascicles were printed in 1854, cite the principal definition of Wirklichkeit in recent Neubochdeutsch (i.e. the German language since Luther) as: 'commonly referring to actions and things that have a sensory perceptible reality'. 21 This perhaps explains Wagner's description of dance - 'the most tangible [realste] of all the arts' - as the sensory perception of physical movements, that is, matter given and received, a physicality doubled. ${ }^{22}$ This much is clear from Wagner's subsequent (gendered) emphasis on physically taking in the dancer's organic figure. Whereas the ornamental gestures of a ballerina are

19 The levels of perceived reality on stage are, of course, measured against the truism that, in opera, 'most of the characters sing most or all of the time', meaning that '[i]n that very obvious sense it is not realistic'. Carolyn Abbate and Roger Parker, A History of Opera: The Last 400 Years (London, 2012), 1.

20 'Diese brutalen Weltbesieger behagten sich nur in der positivsten Realität, ihre Einbildungskraft konnte sich nur in materiellster Verwirklichung befriedigen. Den, dem öffentlichen Leben schüchtern entflohenen, Philosophen ließen sie getrost sich dem abstraktesten Denken überliefern; in der Öffentlichkeit selbst liebten sie, sich der allerkonkretesten Mordlust zu überlassen, das menschliche Leiden in absoluter physischer Wirklichkeit sich vorgestellt zu sehen.' SSD 3: 13. Cf. PW 1: 36. (Die Kunst und die Revolution). Another reading of Wagner's caricature of feckless strength is that it betrays a certain fear of asking how it is with the world, of seeing things for what they are, bereft of ideology. And there is little for the imagination to feed on in such enquiry. Terry Eagleton aptly describes the condition as one of antagonism: 'to bow our minds submissively to the actual requires a humility and self-effacement which the clamorous ego finds hard to stomach. It is an unglamorous business, distasteful to the fantasizing, chronically self-deceiving human mind.' See Eagleton, Figures of Dissent: Critical Essays on Fish, Spivak, Žižek and Others (London and New York, 2003), 87.

21 'allgemein von handlungen und dingen, die eine sinnlich wahrnehmbare realität besitzen, gebraucht'. See http://urts55.uni-trier.de:8080/Projekte/DWB (accessed 18 July 2013).

22 'Die realste aller Kunstarten ist die Tanzkunst.' SSD 3: 71. Cf. PW 1: 100. (Das Kunstwerk der Zukunft) 
'merely art, and not truth', 23 the stuff of dance is actual living man, and indeed not a single part of him, but the whole man from head to toe, as he appears before our eyes'. ${ }^{24}$ The reality concept Wagner is trying to articulate, it seems, is phenomenological: a state of being focused on presence - purely physical perception, fed by real sensory input - is coupled to a quality of reality authorised by the perception of spatial proximity. This very perception of proximity, for the present-day philosopher Hans Ulrich Gumbrecht, is a precondition of lived experience (ästhetisches Erleben) as the culturally specific moment that precedes aesthetic experience proper (ästhetisches Erfahrung), that is, that tissue of contemplative attention which constitutes interpretive acts. ${ }^{25}$ By implication, then, an awareness of distance from the physical dancer moving in space then precedes any aesthetic judgement of his or her art.

Accordingly, references to Wirklichkeit elsewhere are positioned within common philosophical dualisms ('thought, that mere phantom of reality [bloße Bild der Erscheinung], is formless by itself,' 26 where reality is positioned as empirical truth along 'the path of science lead[ing] from error to knowledge; from imagination to reality [Wirklichkeit]'); and by association with ideals of earthy Germanic living ('with the Volk, all is reality and deed [Wirklichkeit und Tat]; it does, and then rejoices in the thought of its own doing'). ${ }^{28}$

But - remaining with Wagner's historically limited conceptions for a moment longer before assigning a materialist value to Wagner's Wirklichkeit, it is worth recalling how sharply he continued to differentiate the sphere of music from this physical-sensory reading of reality. In a typically equivocal statement from Über die Bestimmung der Oper (1871), he orientates the perceived effect of music away from the material, towards the virtual:

seeing how fond people are of ascribing to music, particularly of the passionate and stirring type, a simply pathological character [lediglich pathologisches Element], it may surprise them to discover ... how delicate and purely ideal her actual sphere is, since the material terror of reality [das reale Schrecken der Wirklichkeit] can find no place therein, whereas the soul of all things real [alles Wirklichen] finds pure expression in it alone. ${ }^{29}$

Leaving aside Schopenhauer's influence on such formulations, pure expression defined against 'the material terror of reality' evokes discourses of virtuality by

'[]hr Gebaren ist ja nur Kunst, nicht Wahrheit.' SSD 3: 78. Cf. PW 1: 106. (Das Kunstwerk der Zukunft) 'Thr künstlerischer Stoff ist der wirkliche leibliche Mensch, und zwar nicht ein Teil desselben, sondern der ganze, von der Fußsohle bis zum Scheitel, wie er dem Auge sich darstellt.' SSD 3: 71. Cf. PW 1: 100. (Das Kunstwerk der Zukunft)

25 Hans Ulrich Gumbrecht, The Production of Presence: What Meaning Cannot Convey (Stanford, 2004), 99-100.

26 'der Gedanke, diese bloße Bild der Erscheinung, ist an sich gestaltlos'. SSD 3: 103. Cf 1: 134. (Das Kunstwerk der Zukunft)

27 'Der Weg der Wissenschaft ist der vom Irrtum zur Erkenntnis, von der Vorstellung zur Wirklichkeit.' SSD 3: 45. Cf. PW 1: 72. (Das Kunstwerk der Zukunft)

28 'Bei dem Volke ist alles Wirklichkeit und Tat; es handelt, und freut sich dann im Denken seines Handelns.' SSD 3: 104-5. Cf. PW 1: 135-6. (Das Kunstwerk der Zukunft)

29 Da nun hiergegen der namentlich leidenschaftlich erregten Musik so gern ein ihr innewohnendes lediglich pathologisches Element augesprochen zu werden pflegt, so dürfte es überraschen, gerade an diesem Beispiele zu erkennen, wie zart und von rein idealer Form ihre wirkliche Sphäre ist, weil das reale Schrecken der Wirklichkeit sich nicht in ihr erhalten kann, wogegen allerdings die Seele alles Wirklichen einzig in ihr sich rein ausdrückt.' SSD 9: 152-3. Cf. PW 5: 152-3. (Über die Bestimmung der Oper) 
inscribing a split between lived experience and reality. A pure expression of tragedy with no material reality must, by definition, count as virtual at the level of experience in that it is not our tragedy that we experience, but the vicarious experience of a tragedy we imagine when embodied (simulated) by actors. In this reading, then, stage events - comprising actors' physical presence and heard music - are at once exactly equivalent to reality and yet not what they seem.

When Wagner wanted rhetorically to assert the significance of actors at the beginning of his essay Über Schauspieler und Sänger (1872), he trumpeted them as the 'only reality [Wirklichkeit] of the artistic show for viewers', 30 behind which the composer's agency remains imperceptible: 'the author of the piece has no more to do with the actual "art" [perceived] than insofar as he has planned his poem by calculating the effect it is to produce when acted'. ${ }^{31}$ This statement is reducible neither to the Kleistean puppeteer behind the curtain nor to the Marxian concealment of modes of production; it locates reality within the material surface of perception, even if what is perceived is poetically pre-planned. And it is telling that Wagner actively feared for his actors whose total 'self-divestment' (Selbstentäußerung) of ego and id while acting went beyond deception and the semblance of feeling: 'a thoroughly gifted and accomplished actor [Mime] appears ... to offer up his consciousness of self to such an extent that, in a sense, he never recovers it even in daily life, or at least never completely', he warns. ${ }^{32}$ With this Wagner effectively anticipates a Strasbergean approach to method acting through the view that the degree of an actor's psychological absorption in a role is directly proportional to the power of the effect spectators perceive from the performance: 'the actions and passions of purely fictitious persons thrill us to exactly the same degree as the performer himself is steeped in them, indeed, possessed to the point of completely yielding up his real [realen] personality'. 33 And the 'wondrous' result, in Wagner's extension of Coleridge, is that 'the intent to deceive and be deceived is denied by neither side'. ${ }^{34}$

\section{Simulcasting Wagner and the reproduction paradigm}

Hitherto, I have been concerned with Wagner's conception of 'reality' in the theatre and its particular claims for ontology. The philosophical opposition of appearance

30 'die einzige Wirklichkeit des seiner Apperzeption dargebotenen künstlerischen Vorganges'. SSD 9: 159. Cf. PW 5: 160. (Über Schauspieler und Sänger)

31 'der Verfasser des Stückes [steht] zu der eigentlichen "Kunst" nur soweit mit in Beziehung ... als er die von ihm im voraus berechnete Wirkung der mimischen Darstellung für die Gestaltung seines Gedichtes vor allen Dingen verwertet hat'. SSD 9: 159. Cf. PW 5: 160. (Über Schauspieler und Sänger)

32 'der durchaus geniale, vollendete Mime [scheint] bei jenen Akten der Selbstentäußerung das Bewußtwein von sich in einem Grade aufzuopfern, daß er es in einem gewissen Sinne auch im gemeinen Leben nicht, oder wenigstens nie vollständig wiederfindet'. SSD 9: 217. Cf. PW 5: 216. (Über Schauspieler und Sänger)

33 'die dargestellten Vorgänge und Handlungen rein erdichteter Personen [erschüttern] uns in dem Maße ... wie der Darsteller selbst, bis zur völligen Aufhebung seiner realen Persönlichkeit, von ihnen erfüllt, ja recht eigentlich besessen ist'. SSD 9: 159. Cf. PW 5: 161. (Über Schauspieler und Sänger)

34 'die Absicht und Annahme eines täuschenden Spieles [ist] von keiner Seite je verleugnet'. SSD 9: 159. Cf. PW 5: 161. (Über Schauspieler und Sänger) 
and reality that he sees between contrived qualities (from balletic gesture to abstract philosophy) and raw physical acts on stage (here, dancing) cuts across a wider opposition between art and reality in which art, defined as the cultivation of beautiful appearance, contrasts with the experience of practical, everyday reality. Before looking at how Wagner's suppositions intersect with this wider opposition, it is worth briefly touching upon one instance of the protracted nineteenth-century debate over art and reality.

The Weimar-based theorist Johann Christian Lobe claimed the two were incompatible, warning that 'art remains art and can never be reality [Wirklichkeit]. ${ }^{35} \mathrm{He}$ had in mind the tension between the direct expression and the representation of emotion in vocal lines. The accepted codes of realism in German opera - the scream, the anomalously spoken word, the momentary stage violence - constitute mere appearance when perceived as forms of representation, as a code; when these are taken further, and hence break convention, the illusion of art itself appears vulnerable:

Full naturalism [Naturwabrheit] destroys art ... no one actually sings his fury, his desperation ... But if one could force a man actually to sing of his fury, his desperation, and one wanted - in order to be true to nature - to copy such singing exactly on the stage, everyone would rightly laugh at such natural realism. / Germans take too little heed of this. ${ }^{36}$

(Wagner himself took heed, it seems, cautioning on the need to maintain codes of realism in just this way at the premiere of Parsifal in 1882). ${ }^{37}$ Writing in 1851, Lobe could look back on half a century of aesthetic debate emanating principally from Schiller's claim that the cultivation of beauty can ennoble one's moral character something Marcuse characterised as a liberating force ... envisaged as containing the possibility of a new reality principle'. ${ }^{38}$ But it was liberation into a reality different from one's 'nature', ostensibly. This liberation - implied by Schiller - situated the divorce of nature from art not on the historical grid of taste or individual accountability, but within a dialectic of the natural and the artificial.

Hans-Georg Gadamer concisely summarised the turn this engendered:

Traditionally the purpose of 'art,' which also includes all conscious transformation of nature for human use, was to supplement and fill the gaps left open by nature. And 'the fine arts,' as

'Die Kunst bleibt Kunst und kann niemals Wirklichkeit werden.' J.C. Lobe, 'Vierter Brief. Deutsche Musik', Musikalische Briefe: Wabrbeit über Tonkunst und Tonkünstler (Leipzig, 1852), 22-33, at 31.

36 'Volle Naturwahrheit vernichtet die Kunst ... Kein Mensch singt in der Wirklichkeit seinen Zorn, seine Verzweiflung ... Könnte man aber einen Menschen zwingen, in der Wirklichkeit seinen Zorn, seine Verzweiflung auszusingen und man wollte, um naturwahr zu werden, auf der Bühne einen so Singenden genau copiren, so würde Jedermann mit Recht über solche Naturwahrheit lachen. / Das beachten die Deutschen zu wenig.' Ibid., 31.

37 'The boundary-breaking violence of outbursts of the most painful passion, the natural venting of a deeply tragic subject, can only produce their harrowing effect when the standard of emotional expression which they exceed is observed in general.' ('Das alles Maß überschreitende Gewaltsame in den Ausbrüchen schmerzlichster Leidenschaft, das ja dem tieftragischen Stoffe wie zu seiner Entlastung naturgemäß zugehörig ist, kann nur dann seine erschüttene Wirkung hervorbringen, wenn das von ihm überschrittene Maß eben durchweg als Gesetz der gefühlvollen Kundgebung eingehalten ist.') Wagner, SSD 10: 300. Cf. PW 6: 305. (Das Bübnenweihfestspiel in Bayreuth 1882)

38 Friedrich Schiller, Über die ästhetische Erziebung des Menschen in einer Reibe von Briefen, ed. Stefan Matuschek (Frankfurt am Main, 2009); and Herbert Marcuse, Eros and Civilization: A Philosophical Enquiry into Freud [1956], rpt. (Abingdon, 1998), 180. 
long as they are seen in this framework, are a perfecting of reality, not appearances that mark, veil, or transfigure it. But if the concept of art is defined as appearance in contrast to reality, then nature no longer represents a comprehensive framework. Art becomes a standpoint of its own and establishes its own autonomous claim to supremacy. ${ }^{39}$

In cutting across the familiar divide of art/appearance and reality, Wagner's position is anomalous. Recall that he acknowledged the physical appearance of actors on stage as the 'only reality' that audiences experience. And he saw no feigning or simulation as such in his ideal actor's work - that is, where the authenticity of experience on and off stage were structurally connected. Such a topic easily exceeds the history of Western aesthetics, of course, and a transcultural glance provides us with an alternative, visual frame for measuring the concept of reality. The ninth-century Diamond Sutra, from a collection of Buddhist texts usually classified under the heading 'Perfection of wisdom' (Prajñapāramitāa), closes with a related condition (vis-à-vis Wagner's actor) about images credited as both real and not real, images that draw together the ostensibly opposite as equally 'produced' and 'seen':

Like stars, like an optical illusion, like a lamp, like a magical illusion, dewdrops, or a bubble, like a dream, a flash of lightning or a cloud, so all that is produced is to be seen. ${ }^{40}$

The contemplative moment of such images makes the categorical opposition of art and reality specious, and if we return to modern times, Mikhail Bakhtin - in a critique of art criticism - grounds the point when he argued that what is taken as real in everyday life 'is already essentially aestheticised; it is already an artistic image of reality' as illustrated by the frequent rejection of modern art in favour of classical art, perceived as a kind of 'neutral reality', which is wholly an attribute of the viewer. ${ }^{41}$

In the mediatised culture of the twenty-first century, the concept of reality is not often broached in relation to nineteenth-century opera. But the parallels with Bakhtin's aestheticisation of the 'real' are informative. Just as, for Wagner, the media of voice and instruments do not mix, neither do those of live performance and digital broadcast, it seems. If the visible bodies of performers created stage reality for him, what status might we accord to the pixelated representations of bodies in high definition?

The public premise of opera simulcasting is that it brings the experience of opera faithfully to a mass audience: 'The thrust of our plan is to make the Met more available ... We are in a position of really controlling our content, explained Peter Gelb, the managing director of the Met and instigator of Live in HD for cinema audiences since $2006 .{ }^{42}$ Seen as an expansionist policy motivated by the co-dependent goals of

39 Hans-Georg Gadamer, Truth and Method [1960], rpt. (London and New York, 2004), 71.

40 Cited in Jan Westerhoff, Twelve Examples of Illusions (Oxford, 2010), 7.

41 Mikhail Bakhtin, Art and Answerability: Early Philosophical Essays, ed. Michael Holquist and Vadim Liapunov (Austin, 1990), 276.

42 Daniel J. Wakin, 'The Multiplex as Opera House: Will They Serve Popcorn?’ New York Times (7 September 2006), www.nytimes.com/2006/09/07/arts/music/07unio.html?_r=0 (accessed 19 July 2013). Emphasis added. 
economic survival and social progress, opera simulcasting ostensibly started out as a form of market expansion for the companies, and of telepresence for spectators, a means of virtual transportation to 30 Lincoln Center Plaza, to Covent Garden, San Francisco Opera, LA Opera and so on.

As such, the concept is old: it was inaugurated as the lonely experience of auditory presence in Bell's telephone, and its current summit is capped by vocal interaction with avatars across virtual platforms such as Second Life and Active Worlds. In this historical context, it is worth recalling that the simulcast phenomenon was anticipated closely by Thomas Edison, whose kinetoscope (famously 'do[ing] for the eye what the phonograph does for the ear') specifically mentioned opera as the desired object for this proposed merger of audio with visual technologies in his 1888 caveat:

This apparatus I call a Kinetoscope 'moving view.' In the first production of the actual motions that is to say of a continuous Opera, the instrument may be called a Kinetograph ... By gearing or connecting the Kinetograph by a positive mechanical movement, a continuous record of all motion is taken down on the Kinetograph and a continuous record of all sounds are taken down by the phonograph[,] and by substituting the photograph recording devices on the Kinetograph for a microscope stand and objective, it becomes a Kinetoscope[, as well as] by insertion of the listening tubes of the phonograph into the ear. [sic] [Here] the illusion is complete and we may see and hear a whole opera as perfectly as if actually present although the actual performance may have taken place years before ... By using very large transparent shells the pictures may be even projected on the screen as in microphotographic projection or enlargement. ${ }^{43}$

As Edison's prototype makes clear, the engineering concept began with a paradigm of reproduction that has remained for more than a century and a quarter (and in this sense, simulcasting merely projects recording's storage technology along time's arrow). Nicholas Cook has recently shown how widely the paradigm can be traced, as a symptom of the enduring cultural belief in the faithful reproduction of a priori objects, traceable to the originary mimesis partially captured in a score. $\mathrm{He}$ identifies successive concepts that replicate each other from within: Werktrene $\rightarrow$ 'high fidelity' $\rightarrow$ historic record transfers (the remastering of historic recordings), each of which seeks to erase the fingerprints of later agents of reproduction, whether human or machine:

The discourses of Werktreue - proclaiming the performer's onus of loyalty to the composer and obligation to be a transparent mediator - are replicated by the discourses of 'high fidelity', where the watchwords are faithfulness of reproduction and transparency of sound: just as you should not be aware of the performer but only of the work, so you should not be aware of the reproduction technology but only of the performance. The same discursive categories are applied even within the practices of recording ... [particularly] in relation to the remastering of historical recordings: the aim of transfer engineering is to deploy such techniques as equalisation and noise suppression in such a way as to be both transparent and faithful to the original recording - though this is actually an impossible aim. ${ }^{44}$

43 See: http://edison.rutgers.edu/NamesSearch/DocDetImage.php3 (accessed 19 July 2013).

Emphasis added.

44 Nicholas Cook, 'Beyond Reproduction' unpublished paper given as the inaugural 1684 Professor of Music Lecture at the University of Cambridge (October 2009). 
Yet in the context of cinema, the technological fallacy lurking within is the suspicion, advanced in categorical terms by Michel Chion, that high fidelity has always been a marketing ploy and does not correspond to any originary reality. It is a false assumption, in other words, that ever higher resolution and higher sample rates in new devices, ever greater bit rates and data streams equate to ever greater fidelity to an original sensory reality - what Jonathan Sterne calls 'the dream of verisimilitude'. 45 While definition is a precise technical term relating to the quantity of data used to (re) produce a sound or an image, high fidelity has no such technical reference, as Chion observes:

Current practice dictates that a sound recording should have more treble than would be heard in the real situation (for example when it's the voice of a person at some distance with back turned). No one complains of nonfidelity from too much definition! This proves that it's definition that counts for sound, and its hyperreal effect, which has little to do with the experience of direct audition. ${ }^{46}$

This tension between the reproduction paradigm of opera recordings on the one hand (Cook's Werktreue cubed), and the normative practice of rendering sound in cinema on the other, splits apart the putative 'reality' of the opera simulcast project. For sound that a spectator recognises as true in the cinema and sound that faithfully reproduces an acoustic original are not the same thing:

The film spectator recognises sound to be truthful, effective, and fitting not so much if they reproduce what would be heard in the same situation in reality, but if they render (convey, express) the feelings associated with the situation. ${ }^{47}$

What Chion calls the 'double property of sound' refers to the need for sound not only to identify its source acoustically, but also to evoke impressions linked to this source. Hence we expect cinematic sound actively to carry our perception of the event, to become a microcosm of its entire impression.

We might reply that opera's music already does this on an emotional plane, that that is precisely what is achieved by the semiotic energy of Wagner's orchestra, but sound effects are of a different order. The noise of something that we see falling and crashing to the ground is amplified and enhanced above its acoustic plane, Chion suggests, because of its duty to convey the sense of 'weight, violence, and pain'. ${ }^{48}$ To be sure, this offers possibilities as well as challenges for opera productions. In Wagner's Ring, we might surmise, the clumping size 54 feet of Fasolt and Fafner could, in addition to Wagner's timpani and brass, be signalled by muffled low explosions, as the stage creaks and bows under their heavy tread; Donner's great hammer blow (conjuring the rainbow bridge in Das Rheingold) and the anvil strikes of Siegfried's forging song (in Siegfried) could be 'rendered' so that the puny stage props sound as mighty as the concepts they produce (a bridge of light and re-forged

\footnotetext{
45 Jonathan Sterne, MP3: The Meaning of a Format (Durham and London, 2012), 4.

46 Michel Chion, Audio-Vision: Sound on Screen, trans. Claudia Gorbman (New York, 1994), 98-9.

Ibid., 108-9. Emphasis added.

48 Ibid., 112.
} 
dynastic sword, respectively). In other words, while Chion's codes of realism in film sound ostensibly refer to the use of believable sound effects only, they bleed into the plausible reproduction of opera and its voices in cinema, in principle. Put simply, in a discourse on auditory realism, a clean separation of reproducing and rendering sound is made difficult by the converging expectations of the formerly separate experiences of acoustic opera and cinema sound.

While the engineers of Live in HD appear to be professionally silent on the matter of fidelity, the pursuit of cutting-edge technology is used to market the product. The Met's chief broadcast engineer, Mark Schubin, explains that he incessantly 'note[s] the [technological] trends so I can bring them to the attention of the Met'. ${ }^{49}$ In 2006, this meant high definition and 'fantastic surround sound'; 50 in 2013 Schubin predicted 3D simulcasts 'with and without glasses' as well as instant subtitles in the live interviews. ${ }^{51}$ Yet comparing a real performance to its simulcast is not simple. Just as we cannot distinguish visually or aurally whether what we are experiencing is live (i.e. distinguish between what we take to be "simply "alive" and what as reproduction, separated from its origin, is structurally posthumous'), ${ }^{52}$ so it is difficult to compare live acoustic performance to its digital transmission, except through the subjective screen of memory. ${ }^{53}$ We cannot be in two places at once. Furthermore, some spectators may never have heard a given singer or orchestra live, or even that particular opera before, eliminating the materialising sound indices of prior experience needed for comparison with the mixed, amplified timbre of the voices and instruments. For a live event, the status of 'real' then becomes decoupled from the sensation of an acoustic input.

Ironically, rather than seamless bulletins of breaking news, it is the imperfections of transmission that alert us most reliably to the presence of the live medium. Historically, the difference between the technical and aesthetic quality of live TV transmission and cinema was initially a defect of technology rather than a programmatic concept - it was impossible at first, then merely difficult, to store and broadcast simultaneously. In his critique of the aesthetics of live broadcast, media historian Wolfgang Ernst cites narrative rupture - the emplacement of the unexpected, including signal interference - as the defining transformation of perception brought about by live relay:

The intimate relation of the [live] medium to accidents and catastrophes can also be recognized in war coverage ... From this perspective, the most expressive television image of

49 See: http://operalively.com/forums/content.php/848-The-Exclusive-Opera-Lively-Interviewwith-Mark-Schubin-media-engineer-at-the-Met (accessed 19 July 2013).

50 Peter Gelb's statement, cited in Daniel J. Wakin, 'The Multiplex as Opera House'.

51 Marc Schubin interview with Luiz Gazzola, OperaLively.com (29 June 2013), http://operalively.com/ forums/content.php/848-The-Exclusive-Opera-Lively-Interview-with-Mark-Schubin-mediaengineer-at-the-Met (accessed 21 July 2013); and David Patrick Stearnes, 'Opera on the Big Screen', The Inquirer (27 December 2006), http:/ /articles.philly.com/2006-12-27/news/

25399564_1_bellini-s-i-puritani-opera-fans-simulcast (accessed 21 July 2013).

52 Samuel Weber interviewed by Cassi Plate in 'Deux ex Media', in idem, Mass Mediaurus: Form, Technics, Media (Stanford, CA, 1996), 160.

53 One attempt at this is Wayne Gooding, 'Better on the Big Screen', The Wagner Journal 5 (2011), 82-7. 
war is the interruption of transmission, the sudden halt of all images: the empty screen immediately documents the explosion of a bomb, for instance, in Belgrade's state-owned TV station, and becomes an allegory of death, which itself is not visible. ${ }^{54}$

The order of signs shifts from iconic to symbolic, in other words. Such an exposé of the narrative and semantic quality of normative screen images reminds us that there is a performative element in the making public of the ongoing present. And the medium of broadcast is structurally linked to this element. Of course, stage performance replicates this vulnerability in microcosm through its capacity for fluffed lines, cracked notes and missed entries, all of which, though, remain defined in relation to a concept of the work's prior immutability, however difficult this is to sustain for an aesthetics of opera.

Paradoxically, all Met broadcasts are recorded as live, problematising the performance mode that Ernst calls 'an aesthetics of the permanent broadcast'. 55 Schubin confirms that in Met simulcasts: 'for the media department, everything we do is live; future playback is based on the live recording. ${ }^{56}$ The sound mixes are adjusted in real time for typical surround-sound speaker placement at home (behind the listener) and in cinemas (in front of the listener). Both audio environments are different to binaural human hearing - immersive, but without the programming for actual 3D audio. Here, then, Gelb's 'fantastic[al] surround sound' becomes more than a figure of speech.

In light of this, the simulcast via digital cinema is only superficially an agent of telepresence. Accepting the mutual pact of deception Wagner ascribed to staged performance, we are not actually duped by the thin reality of the cinema screen in this venue of the solitary fantastical. While there are a number of reasons for this, sociological as well as technological, I shall touch here on the auditory environment in its kinship to sound recording, as this draws out the conflict between reproduction and rendering broached above.

\section{Upmix problems}

On 1 November 2011, online trade forums relayed a press release that announced Wohler Technologies would be supplying stereo-to-5.1 upmix processors (UPM-1s) to All Mobile Video (AMV), the Met's Live in HD broadcaster: 'The UPM-1 systems will be used among AMV's various O[utside] B[roadcast] vehicles ... at its Gateway teleport station in New Jersey to upmix audio for opera simulcasts from the Met in New York. ${ }^{, 57}$ In this context, upmixing refers to the process of taking an audio input with $\mathrm{x}$ channels and turning it into an output with $>\mathrm{x}$ channels, typically from a stereo (two-channel) source to a 5.1-channel speaker environment. Because of the

54 Wolfgang Ernst, Digital Memory and the Archive (Minneapolis and London, 2013), 106.

55 Ibid., 111

56 Marc Schubin interview with Luiz Gazzola, OperaLively.com (29 June 2013), http:/ /operalively.com/ forums/content.php/848-The-Exclusive-Opera-Lively-Interview-with-Mark-Schubin-mediaengineer-at-the-Met (accessed 21 July 2013).

57 Anon., 'Wohler Supplies Sound Field Stereo-to-5.1 Upmixers to All Mobile Video', Broadcast Engineering (10 November 2011), http://provideocoalition.com/news/story/wohler_supplies_ soundfield_upm-1_stereo-to-5.1_upmixers_to_all_mobile_video/ (accessed 20 July 2013). 
number of editing houses and production variables involved in receiving simulcast transmissions, upmixing is a 'common requirement' since not all receiving institutions can handle a discreet channel mix in $5.1^{58}$

But any upmixing of a stereo input from the theatre into immersive surroundsound washes away the spectator's sense of occupying a fixed position in threedimensional space. The resulting six channels of sound contain ambient replication of the stereo-mix in its newly discreet, or 'upmixed' channels. This produces an immersive experience that denies listeners any auditory points of orientation. Whether or not we relish this as a technological 'sea of harmony', the auditory environment it creates is a pure simulacrum in Baudrillard's sense of simulating an original whose status as 'real' no longer exists as such. Just as a simulated bank robbery inevitably becomes real in its consequences (Baudrillard's example), or synthetic vitamin $\mathrm{C}$ is indistinguishable from its natural counterpart at the pharmacy counter, the cinema simulcast is the only 'real' performance for many more listeners than the in-theatre event. Why? Because simulated art is a pleonasm that reveals our need to define art as real at the level of experience, or in political terms, our subscription to 'the weight of an order that cannot see and conceive itself of anything but the real, because it cannot function anywhere else ... It is no longer a question of a false representation of reality (ideology) but of concealing the fact that the real is no longer real, and thus of saving the reality principle'. ${ }^{59}$ This downgrades the status of the live-in-the-theatre event, in other words; it is no longer 'real' (and hence primary) because of its immediacy to the sound source, nor - in an age of infinite digital replication - is it conceptually prior to a mediatised version of the live event. For some, then, recordings can aspire to little more than an inferior substitute for 'real music, music-as-performed'; ${ }^{60}$ another view, one closer to Baudrillard's bank robbery, is that sound recording technologies are not restricted to 'inferior simulations of reality', as Michael Veal puts it, but their 'creative manipulations ... create new forms of reality (that is, new ways of "hearing" the world). ${ }^{61}$ Shoring up this critique is the obvious corollary that the phalanx of microphones in the opera house is in no way analogous, or morphologically similar, to binaural listening. ${ }^{62}$

Of course, it has been possible for some time to mimic the process of natural acoustic hearing using a 3D audio system; with sufficient data rates, it would be possible for simulcast opera to use independently coded channels and generate more

58 Ibid.

59 Jean Baudrillard, Simulacra and Simulation [1981], trans. Shiela Faria Glaser (Ann Arbor, 2010), 12-13, 20.

60 Carolyn Abbate, 'Music - Drastic or Gnostic?', Critical Inquiry 30 (2004), 505-36, at 532.

61 Michael Veal, Dub: Soundscapes and Shattered Songs in Jamaican Reggae (Middletown, CT, 2007 ), 218.

62 'There are typically 10 or 11 microphones in the orchestra pit, generally one for each orchestra section; the harp usually gets its own mic. For the singers, the basic pickup is four pairs of microphones across the lip of the stage: left, left center, right center, and right. Each pair has a short shotgun for distant pickup and a cardioid for closer pickup. There are three distant microphones in the house for ambiance pickup.' Mark Schubin interview with Opera Lively (29 June 2013), http:/ / operalively.com/ forums/content.php/848-The-Exclusive-Opera-Lively-Interviewwith-Mark-Schubin-media-engineer-at-the-Met. 
accurate 3D environments. But these would still be generic vis-à-vis individually shaped bodies. William Gardner, a sound engineer specialising in 3D audio using loudspeakers, explains that:

Both ears are subject to a complicated filtering process caused by acoustical interaction with the torso, head, and in particular, the pinna (external ear). The various folds in the pinna modify the frequency content of the signals, reinforcing some frequencies and attenuating others, in a manner that depends on the direction of the incident sound. Thus an ear acts like a complication tone control that is direction dependent. ${ }^{63}$

By inserting tiny microphones into the ear canals of a mannequin, it is possible to model and hence measure the transformation of sound from a point in space to the ear canal. As well as quantifying an individual listener's physiological properties, described above by Gardner, these measurements ('head-related transfer functions'), calculate the minute time lag between sound signals striking the right and left ears that allow us to determine the spatial location of a sound source. These sound localisation cues can then be replicated in an 'ambisonic' file that encodes spatial coordinates as a set of four vectors, that is, in a form that is not directly related to the number of speakers available in a performance venue, making a spatial design portable for music. (While digital sound files imply a fixity of performance that seemingly precludes 'interpretation', they still need to be realised by a speaker configuration in a theatre. The warning voices are ready: the electro-acoustic composer Ambrose Field has argued that spatialisation is an essential variable of performance in this sense: 'if the piece is delivered 'pre-diffused' [i.e. where sound diffusion within an environment is encoded] then what is there left to perform? ${ }^{64}$ The audio engineer David Moulton argues for the centrality of the speaker choice, that 'the sound quality we perceive [in mediatised performance] comes primarily from the loudspeaker and via the room, not from the quality of its supporting electronics'. ${ }^{5}$ And with Adorno's performance theory in mind, Elizabeth Hoffman has similarly asserted that spatialisation, speaker placement, equalisation and amplitude balance all constitute aspects of a 'work' and ought to be identified with its ontology: 'equalisation may affect our perception of attack times; and speaker placement may affect our perception of speed and timing. ${ }^{66}$

So the mediatised reality of an opera's sound, beamed as a set of binary instructions, is reconfigured differently in different locations. The simulcast performs simultaneously in different ways, making the acoustic event differently 'real'.

63 William G. Gardner, ‘3D Audio and Acoustic Environment Modeling' (15 March 1999), 2, http:// web.cs.wpi.edu/ gogo/hive/papers/Gardner_WaveArts_1999.pdf (accessed 1 July 2013). See also, Gardner, ‘3-D Audio Using Loudspeakers', Ph.D. dissertation, MIT (1997), http://sound. media.mit.edu/Papers/gardner_thesis.pdf (accessed 21 July 2013).

64 Larry Austin and Ambrose Field, 'Sound Diffusion in Composition and Performance Practice II: An Interview with Ambrose Field', Computer Music Journal 25 (2001), 21-30, at 23.

65 David Moulton, 'The Loudspeaker as Musical Instrument' (May 2003), www.moultonlabs.com/ more/loudspeaker_as_musical_instrument/P0/ (accessed 2 October 2013).

66 Elizabeth Hoffman, 'On Performing Electroacoustic Musics: A Non-idiomatic Case Study for Adorno's Theory of Musical Reproduction', Organised Sound 18 (2013), 60-70, at 64. 
The four-dimensional, audio-visual 'reality' of spectating live in the theatre could be technologically encoded and transmitted far more faithfully through 3D audio and fixed stereoscopic vision, but this form of avatar experience (the experience of virtual presence in the opera house) is not a commercial priority, it seems.

Given simulcast opera's technological dislocation from reality, then, what is the conceptual place of satellite-connected cinema? (While famous open-air ball parks have hosted free opera simulcasts for thousands in San Francisco and Dallas, these remain anomalies against the cinematic experience). The French anthropologist Marc Augé put forward the hypothesis that 'super modernity produces non-places, meaning places which are not themselves anthropological places and which, unlike Baudelairean modernity, do not integrate with earlier places'. If 'place' is defined by interacting bodies - pedestrians in a piazza, passengers on a platform - an anthropology of movement that creates relational or historical identity, 'non-place' is that of a world 'where people are born in the clinic and die in hospital ... a world ... surrendered to solitary individuality'. ${ }^{67}$ We might say it is peopled by users rather than producers of culture.

As an environment of fantastical escape that minimises human interaction, cinema's darkened space and sensory hyperrealism would seem a viable candidate for a 'non-place' in Augés terms. For simulcasting inverts the social experience of opera with its boxes, dress codes, implicit hierarchies and the enforced social mixing of the intervals. It turns the live, public event into a real-time private, even intimate, moment and - phenomenologically speaking - into an interaction with a non-human interlocutor: 'the space of non-places creates neither singular identity nor relations; only solitude, and similitude' (p. 103). The fact that Augés exemplar of the condition of super modernity is the airline passenger - 'alone, but one of many ... in contractual relations with [a non-place]' (p. 101) - underscores the anonymity acceded to by users of the simulcast, the loss of outward presence that inverts the social window of the front stalls or the balcony box: 'Subjected to a gentle form of possession ... [the user of a non-place] tastes for a while - like anyone who is possessed - the passive joys of identity-loss, and the more active pleasure of role-playing' (p. 103). It is perhaps for this reason that media theorist Lev Manovich has interpreted Augé's passenger not as a traveller boarding a fuelled plane, but as a 'user of the flight simulator'. 68

The advertised agent of telepresence - of virtual travel to an opera house via the data of latent, encoded reality, all the while reclining in the 'airline seats' of your local cinema - is ultimately less accurate than the analogy of entering a flight simulator: we travel nowhere, and willingly engage in an artificially immersive experience, as suggested earlier.

All of this is to confirm that the media of live opera and simulcast do not mix. The operation of simulcasting live acoustic stage events mobilises a tension between, on the one hand, obligations to the sensory reality of the performance space (where the

67 Marc Augé, Non-Places: An Anthropology of Supermodernity, trans. John Howe (London, 1995), 78.

68 Lev Manovich, The Language of New Media (Cambridge, MA, 2001), 280. 
priorities are those of replication and mimesis) and, on the other, the need to ensure a stimulating cinematic experience, repurposing the acoustic product for the hyperrealism of digital cinema.

Histories of simulcasting opera are quick to point out the project's long tradition. ${ }^{69}$ But as journalists on both sides of the Atlantic reported in 2006, it was the fiscal necessity of revitalising the Met's ticket sales and generating new revenue streams that provided the impulse towards regular simulcasting each season: 'you cannot continue doing the same thing if your finances are haemorrhaging', Andrew Clarke of the Financial Times cautioned, while Ed Pilkington predicted in the Guardian that 'unless new [audience] blood is brought in the artistic and financial future is precarious. ... [The Met] narrowly avoided going into debt last year. ${ }^{70}$ To posit the medium of simulcasting as a deus ex machina to the fiscal troubles of antique patronage is to brush against discourses of technological utopianism. Nevertheless, Jacques Attali's influential model of music and cultural production reminds us that an economy based in mass reproduction of cultural products (an aesthetic of repetition as applicable to social protocols and canonical works as to sound recordings) emerges when the production of unique cultural objects is no longer profitable. ${ }^{7}$ If we extend the value of 'uniqueness' to performance events, as well as to new compositions, Attali's analysis would seem equally applicable to the simultaneous repetition of old operas in cutting-edge cinemas. The 'extreme occasion' of performance, in other words, is no longer profitable in its acoustic form, giving life to the mediatised event on its own terms. ${ }^{72}$

\section{Delivery technologies}

If the cinematic simulcasting of opera eschews claims for reality, how does the music of opera fare when the connection to an acoustic event is severed altogether? Recall that Wagner did not believe voices and instruments were equivalent in opera (and hence could neither substitute for, nor duplicate, each other). A basic claim of the preceding section is that while the 'content' of live opera flows unchanged as data streams between opera house and cinema multiplex, the cultural product is different in its realisation. A modern parallel is the convergence of media platforms that allows the digital content of operas to migrate between devices (smart phone, tablet, ipod, laptop, cinema, in-flight screen), resulting in different realisations of that content, but ostensibly without affecting its ontology (i.e. still in an idealist work-to-performance relationship).

69 Martin Barker, Live to Your Local Cinema: The Remarkable Rise of Livecasting (Basingstoke, 2013), 5ff.

70 The three problems reported were falling donations, an oversize auditorium averaging 77 per cent attendance in 2005-6, and an ageing demographic. See Andrew Clarke, 'Change of Course for a Met Supertanker', Financial Times (24 February 2006), www.ft.com/cms/s/0/47d7d220-a4db-11da-897c0000779e2340.html (accessed 20 July 2013); and Ed Pilkington, 'Streetwise Met Kickstarts Revival with Puccini on the Pavement', Guardian (27 September 2006), www.guardian.co.uk/world/2006/sep/27/ usa.arts (accessed 20 July 2013). See also Wakin, 'The Multiplex as Opera House'.

71 Jacques Attali, Noise: The Political Economy of Music (Manchester, 1985).

72 Edward Said, 'Performance as an Extreme Occasion' [1989], in idem, The Edward Said Reader (London, 2001), 317-46. 
One of the signal qualities of any digital content is of course its binary coding. Conceptually, this grows out of the rhetoric of binary meaning, dualisms of an earlier age, items - whether concepts or bits - that distinguish this thing from that, hence a processing tool in cognition before computers. Stig Stenholm, in a critique of the breakdown of epistemological certainties during the twentieth century, put it succinctly: "When philosophy aimed at certainty it turned to mathematics. ${ }^{73}$ For some, the code resulting from audio-visual media lays claim to a fully quantified 'reality' where all sensory experience is dissolved into a string of numbers, or as Manovich defines it categorically: 'when all dimensions that affect the reality effect detail, tone, colour, shape, movement - are quantified'. ${ }^{74}$ With a historical purview, Ernst sees this habit of relating reality to a set of numbers as 'a cultural-technological Möbius loop between Greece in the 5th century BC and the present', ${ }^{75}$ in which current practice shadows a Pythagorean worldview with its equally numerical epistemology. In short, both understand reality through the organising frame of mathematics. Yet the corollary assumption that the binary bits of digital signals ensures their immutability when opened (or 'performed'), translating into identical media-sensory experiences no matter where the digital information is received and decoded, is fallible, as the trio of electro-acoustic practitioners quoted above made clear. This is why, for Hoffman, the digital file of an electro-acoustic composition is only 'the work's intermediary form' where, 'like notation, [its] information coexists with contingent properties which arise distinctively in each performance'. ${ }^{76}$

Here, the distinction between medium and delivery technology forms the basis of Henry Jenkins's explanation for why old and new media have coexisted rather than superseded one another: media inculcate social processes (or 'protocols' in Lisa Gitelman's terms) ${ }^{77}$ that last by creating relationships, serving as sites for the ongoing negotiation of cultural meaning. ${ }^{78}$ (The opera theatre is a medium in this sense, and the relatively late inauguration of regular simulcasts, for instance, arguably has more to do with cultural elitism than technological means). What Jenkins memorably dubbed 'convergence culture' refers to new media that allow the same content to flow through multiple platforms and networks, and 'assume many

73 Stig Stenholm, The Quest for Reality: Bohr and Wittgenstein - Two Complementary Views (Oxford, 2011), 2.

74 Lev Manovich, 'The Aesthetics of Virtual Worlds: Report from Los Angeles', Ctheory (22 May 1996), http://manovich.net/TEXT/virt-space.html (accessed 22 July 2013).

75 Ernst, Digital Memory and the Archive, 157.

76 Hoffman, 'On Performing Electroacoustic Musics', 63, 65. Emphasis added.

77 Gitelman has argued that while delivery systems are technological tools, media involve the formation of social processes through 'protocols', that is, 'that you answer "Hello?" and that you pay the company, but also standards like touch-tones and twelve-volt lines ... [Hence,] new media are less points of epistemic rupture than they are socially embedded sites for the ongoing negotiation of meaning as such'. See Gitelman, Always Already New: Media History and the Data of Culture (Cambridge, MA, 2006), 5-6.

78 'Delivery systems are simply and only technologies; media are also cultural systems ... Printed words did not kill spoken words. Cinema did not kill theatre. Television did not kill radio. Each old medium was forced to coexist with the emerging media ... Old media are not being replaced. Rather, their functions and status are shifted by the introductions of new technologies'. Henry Jenkins, Convergence Culture: Where Old and New Media Collide (New York, 2008), 14. 
different forms at the point of reception'. ${ }^{79}$ It sees the interaction of old and new media as part of an emerging cultural economy that connects established and emerging media institutions, expanding the number of contributors and players, particularly via open-source platforms (such as YouTube, Vimeo and Daily Motion).

Since Friedrich Kittler's pioneering article Weltatem in 1987, readings of Wagner's works in terms of media history have proliferated. ${ }^{80}$ In that tradition, we might draw the strands together and say that, just as the same melody performed by a soubrette or oboe is not equivalent for Wagner, so melodies 'performed' in amplified 5.1 cinema sound in London are not equivalent with those heard in Phoenix or via the sound card of your home computer in Nairobi, let alone in an acoustic theatre in New York. ${ }^{81}$

And this condition is infinitely multiplied across the media terrain. Eschewing recordings or broadcasts that maintain a putative link to the 'reality' of the performance event they transmit are the platforms and devices that quote musical material for special or comic effect. Verisimilitude is neither dreamt of nor desired in a domain interested in the present association but not the history of sounds; for Baudrillard, history explicitly becomes 'our lost referential' in such media, and its absence 'leaves behind it an indifferent nebula' that at once opens up the free play of cultural association across media platforms and diminishes the power of association. ${ }^{82}$ To take perhaps the most clichéd, and hence widely disseminated, theme from a Wagner opera, the dotted arpeggios in the Prelude to Act III of Die Walküre notably codified as die Figur des Walkürenrittes in Hans von Wolzogen's 1876 booklet accompanying the premiere of the complete cycle ${ }^{83}$ - chimes out from mobile phones, video-game consoles, anime and Western animation, TV advertising, liveaction TV, multifarious films, as well as Pro Wrestling and web comics. ${ }^{84}$ In the case

79 Ibid., 11.

80 Friedrich Kittler, 'Weltatem: On Wagner's Media Technology', in Wagner in Retrospect, ed. Leroy R. Shaw, Nancy R. Cirillo and Marion Miller (Amsterdam, 1987), 203-12. The touchstone for almost all readings of Wagner-as-acoustician over the last decade have been the 136 bars of sustained E-flat major that open Das Rheingold (though the realist echoes of sailors in Der fliegende Holländer and Tristan, the tonal portraits of acoustic distance in Lohengrin, and the calculation of bell resonance in Parsifal would have equally worthy claims). In fact, Kittler's celebrated reading of the Prelude to Rheingold as a 'vocal physiological dream... a transition from a logic to a physics of sound' plays lip service to Wagner's (unprovable) biographical account of the Prelude's genesis: that he suffered a feverish night at La Spezia, tossing and turning, shivering, semi-conscious and with a high temperature. A tacit assumption within Kittler's media-aesthetic reading is that the sustained E-flat frequencies are a kind of auscultation, then - literal internal aurality - refined either psychologically by Wagner's cognitive musical sense, or artistically, for ears in the opera house.

81 The social scientist Ithiel de Sola Pool predicted this convergence back in 1983, which can easily be read in terms of opera distribution technologies: 'a service [live opera] that was provided in the past by any one medium - be it broadcasting, the press, or telephony - can now be provided in several different physical ways. So the one-to-one relationship that used to exist between a medium and its use is eroding'. See de Sola Pool, Technologies of Freedom: On Free Speech in an Electronic Age (Cambridge, MA, 1983), 54.

82 Baudrillard, Simulacra and Simulation, 44-5.

83 Hans von Wolzogen, Thematische Leitfadendurch die Musik, zu Richard Wagners Festspiel, 'Der Ring des Nibelungen', 2nd edn (Leipzig, 1876), 52.

84 A detailed database of the use of this theme within these media platforms is given on the TV Tropes site: http://tvtropes.org/pmwiki/pmwiki.php/Music/RideOfTheValkyries (accessed 22 July 2013). 
of video games, Wagner's theme, filtered through the massifying lens of Francis Ford Coppola's film Apocalypse Now (1979), has attained a new identity within war gaming. In Coppola's film, we recall, it is heard as proudly diegetic music that Lieutenant Colonel Bill Kilgore plays from speakers mounted on a helicopter gunship as he presides over the bombing of a Vietnamese village:

Kilgore: We'll come in low out of the rising sun, and about a mile out we'll put on the music.

Lance: Music?

Kilgore: $\quad$ Yeah, I use Wagner. Scares the hell out of the slopes. My boys love it. Lance [to nonchalant machine gunners on board] Hey, we're gonna play music! ${ }^{85}$

Coppola's intended historical reference to the sadistic cruelty of Nazi Germany alongside Hitler's interest in Wagner's music (and extended family) has been vastly outweighed by the cultural trope it unleashed for the gaming and film industries since the 1980s. In a majority of war games, as Table 1 shows, the theme is often played at the appearance of a military helicopter, sometimes unexpectedly and occasionally for comic effect.

As well as being merely emotive or comic, associative sound cues in games serve a practical purpose. They are points of orientation that help players to identify goals and focus attention on particular objects. Playing the game without audio remains possible, of course, but - as Karen Collins argues - this typically makes it harder to progress through the different levels:

Symbols and leitmotifs [sic] are often used to assist the player in identifying other characters, moods, environments, and objects, to help the game become more comprehensible and to decrease the learning curve for new players. ${ }^{86}$

Gaming provides only the most commercially available virtual environment based on sensory immersion and real-time interactivity. Not coincidentally, it also appears to be a known engine of media convergence. Jenkins reported a consensus among industry experts from 2003 that the game console, as both inexpensive and accessible, should become "the "black box," the "Trojan horse" that smuggled convergence culture right into people's living rooms."

Methodologically, the flipside of media convergence (between different devices) is literary analogy (between different objects), and I would not be the first to find Wagner's aesthetics resonating with an integrated virtual reality that modern gaming aspires to. On the one hand, an anonymous gaming blogger claimed in 2012 that:

In a totally different, more intimate way, video games encompass so many avenues for artistry that I believe they could be considered to be a total artwork ... Wagner imagined a 'Gesamtkunstwerk,' and I think that video games, even more so than opera, have that ability

85 Ironically from the perspective of constructing 'reality', YouTube user Nicholas Schubert comments on the HD clip of this section from the film: 'it's scenes like this that make you want to get surround sound for your television'. See comment posted 30 June 2013 by Nicholas Schubert, www.youtube.com/watch?v=GKaYOW9zMoY (accessed 21 July 2013).

86 Karen Collins, Game Sound: An Introduction to the History, Theory, and Practice of Video Game Music and Sound Design (London and Cambridge, MA, 2008), 130.

87 Jenkins, Convergence Culture, 8. 
Table 1: Video games that quote Wagner's Walkeürenritt

\begin{tabular}{|c|c|c|c|}
\hline Game & Designer/Date & Platform & Die Walkeüre quotation \\
\hline Satan's Hollow & Bally Midway (1982) & Arcade Game/Commodore 64 & Opening theme \\
\hline $\begin{array}{l}\text { Gunship (AH-64 } \\
\text { Apache flight } \\
\text { simulator) }\end{array}$ & MicroProse (1986) & $\begin{array}{l}\text { Amiga/Amstrad/Atari/ } \\
\text { Commodore 64/FM } \\
\text { Towns/MSX/Sega Mega } \\
\text { Drive }\end{array}$ & Main game theme \\
\hline $\begin{array}{c}\text { Where in the World is } \\
\text { Carmen Sandiego? }\end{array}$ & $\begin{array}{l}\text { Brøderbund Software } \\
\text { (1985) }\end{array}$ & - & $\begin{array}{l}\text { Theme plays during flying } \\
\text { scenes }\end{array}$ \\
\hline Parodius & Konami (1988) & MSX & Theme for the sixth planet \\
\hline Gokujō Parodius & Konami (1994) & Arcade game & $\begin{array}{l}\text { On reaching the special stage } \\
\text { (space battleship Moai } \\
\text { revisited) }\end{array}$ \\
\hline Return Fire & $\begin{array}{l}\text { Silent Software } \\
\quad(1995-6)\end{array}$ & Playstation/Windows & $\begin{array}{l}\text { Whenever the player flies a } \\
\text { helicopter }\end{array}$ \\
\hline Air Cavalry & $\begin{array}{l}\text { Synergistic Software } \\
\text { (1995) }\end{array}$ & Super NES & Main game theme \\
\hline Sim Copter & Maxis (1996) & Windows & $\begin{array}{l}\text { Theme available from the } \\
\text { 'classical station' }\end{array}$ \\
\hline Star Craft & $\begin{array}{l}\text { Blizzard Entertainment } \\
\text { (1998) }\end{array}$ & Windows/Nintendo 64 & $\begin{array}{l}\text { Siege Tank driver hums the } \\
\text { theme if clicked repeatedly }\end{array}$ \\
\hline $\begin{array}{l}\text { Firearms (Game Mod- } \\
\text { Half-Life) }\end{array}$ & $\begin{array}{l}\text { Firearms Development } \\
\text { Team (1998) }\end{array}$ & Windows/Linux & Theme of the rescue helicopter \\
\hline Spiderman & Neversoft (2000) & $\begin{array}{l}\text { Play Station/Game Boy/ } \\
\text { Nintendo 64/Dreamcast/ } \\
\text { Windows }\end{array}$ & $\begin{array}{l}\text { A helicopter pilot starts singing } \\
\text { this theme while shooting at } \\
\text { Spiderman }\end{array}$ \\
\hline Soldier of Fortune 2 & Raven Software (2002) & Windows/Mac OS/Xbox & Theme for scene in Columbia \\
\hline Hearts of Iron I \& III & $\begin{array}{l}\text { Paradox Development } \\
\quad \text { Studio (2002) }\end{array}$ & Windows/Mac OS/Mac OS X & Main theme tune \\
\hline Battlefield Vietnam & $\begin{array}{l}\text { Armando 'AJ' Marini } \\
\text { (2004) }\end{array}$ & - & $\begin{array}{l}\text { An optional song to hear on } \\
\text { the 'radio' }\end{array}$ \\
\hline Nintendogs & $\begin{array}{l}\text { Nintendo EAD Group } \\
\quad 1 \text { (2005) }\end{array}$ & Handheld Nintendo & $\begin{array}{l}\text { When user uses the toy } \\
\text { helicopter }\end{array}$ \\
\hline Punch-Out!! & $\begin{array}{l}\text { Next Level Games } \\
\text { (2009) }\end{array}$ & Wii & $\begin{array}{l}\text { Introductory music for Von } \\
\text { Kaiser }\end{array}$ \\
\hline
\end{tabular}


Table 1: (Continued)

\begin{tabular}{|c|c|c|c|}
\hline Game & Designer/Date & Platform & Die Walkeüre quotation \\
\hline Just Cause 2 & $\begin{array}{l}\text { Avalanche Studios } \\
\text { (2010) }\end{array}$ & $\begin{array}{l}\text { Windows/Play Station/Xbox/ } \\
\text { Cloud (OnLive) }\end{array}$ & $\begin{array}{l}\text { Main character sings this if } \\
\text { enough destruction is caused } \\
\text { in a helicopter }\end{array}$ \\
\hline Far Cry 3 & $\begin{array}{l}\text { Ubisoft Montreal } \\
\text { (2012) }\end{array}$ & Windows/PlayStation/Xbox & $\begin{array}{l}\text { Theme for (i) villain Hoyt after } \\
\text { he blows up hostages; (ii) } \\
\text { escape by helicopter of Jason } \\
\text { and Riley }\end{array}$ \\
\hline Borderlands 2 & $\begin{array}{l}\text { Gearbox Software } \\
\text { (2012) }\end{array}$ & $\begin{array}{l}\text { Windows/PlayStation/Xbox/ } \\
\text { Mac OS X }\end{array}$ & $\begin{array}{l}\text { The bandit pilot of one of the } \\
\text { aircraft sings the theme }\end{array}$ \\
\hline
\end{tabular}

Data reproduced from TV Tropes site:

http://tvtropes.org/pmwiki/pmwiki.php/Music/RideOfTheValkyries (accessed 22 July 2013)

to produce [an] all-encompassing, engaging work of art. And I think that we are steadily approaching that final goal. ${ }^{88}$

On the other hand, Slavoj Žižek takes the opposite approach. Inspired by the Wachowski brothers' film The Matrix, he views Wagner's Parsifal as a game-in-waiting: Klingsor's kingdom in Act II is:

a domain of digital phantasmagoria, of virtual amusement ... Is Klingsor not a kind of Master of the Matrix, manipulating virtual reality ...? And when we pass from Act II to Act III, do we not effectively pass from fake virtual reality to the 'desert of the real' ... Is Parsifal not a model for Keanu Reaves in The Matrix, with Laurence Fishburne in the role of Gurnemanz? ${ }^{89}$

Žižek's provocative intent aside, Wagner's stage directions read differently when conceived as the effects of a coded virtual environment. No longer 'literally "over the rainbow" 90 in the context of nineteenth-century stage technology, they become entirely plausible as 'digital phantasmagoria' - the encoded reality of a digitised medium, whether as data streams or numbers in a digital archive. The navigable space that confronts Parsifal in Act II is that of the screen, and his gaze on the phantasmal garden becomes a 'mobilised virtual gaze' that, for Anne Friedberg, combines two conditions that link one's proprioception to a virtual environment: 'a received perception mediated through representation', it also 'travels in an imaginary flânerie through an imaginary elsewhere and an imaginary elsewhen'. 91 Together for Friedburg - these characterise modern cyber and televisual cultures.

88 See Another Gamer's Blog, http:/ / anothergamersblog.wordpress.com/2012/04/06/wagner-andvideo-games/ (accessed 21 July 2013).

89 Slavoj Zižek, "Foreword: Why is Wagner Worth Saving?", in Adorno, In Search of Wagner, xxiv.

90 Chris Walton, Richard Wagner's Zurich: A Muse of Place (Rochester, NY, 2007), 249.

91 Anne Friedberg, Window Shopping: Cinema and the Postmodern (Berkeley and Los Angeles, 1994), $2 \mathrm{ff}$. 
That Wagner's written description of virgins and vegetation arguably evokes the earthly carnal paradise of Goethean Italy (the Italienische Reise), itself a literary fantasy based on putatively real experience, only underscores the aptness of regarding Wagner's stage imagination in virtual terms.

[Klingsor] rapidly sinks with the whole tower; at the same time the magic garden rises and fills the whole stage. Tropical vegetation, luxuriant display of flowers; towards the rear the scene is bounded by the battlements of the castle walls, flanked by projecting parts of the castle itself, with terraces.

Upon the rampart stands Parsifal, gazing down into the garden in astonishment. From all sides beautiful maidens rush in, first from the garden, then from the palace, in wild confusion, singly then in numbers; they are clad in soft-coloured veils hastily donned, as if just startled out of sleep.

... As Parsifal comes ever nearer to the excited groups, the maidens of the first group and of the first chorus slip away unperceived behind the banks of flowers to complete their floral adornment. ... [They] return wholly dressed in flowers, looking like flowers themselves, and at once rush upon Parsifal.

[End of Act II] ... The castle sinks as if by an earthquake. The garden swiftly withers to a desert; faded flowers are strewn on the ground. ${ }^{92}$

Wagner implicitly rationalises this through Schopenhauer's theory of dreaming (Parsifal: 'Have I just dreamt all this?'), ${ }^{93}$ which - we recall - posited dreams as 'second sight ... a faculty of intuitive perception which has been shown to be independent of the external impress on the senses' which is to say, a simulation from within. ${ }^{94}$ And to date, reading opera plots and stage directions in terms of the virtuality of computer games has found traction in the realm of game theory more than in media simulation. ${ }^{95}$ Attempts have nevertheless been made to adapt Wagner's works themselves to the meta-language of new media. The game Ring: The Legend of the Nibelungen (1999) by Arxel Tribe for Cryo Interactive was followed by Ring II: Twilight of the Gods (2002), both of which used sound cues from Decca's complete recording of the Ring cycle with Sir George Solti. ${ }^{96}$ That both games were critical and commercial failures is perhaps indicative of the riskily discursive nature of such opera-gaming comparisons. ${ }^{97}$

92 Richard Wagner, Sämtliche Werke, 31 vols. [projected], ed. Egon Voss (et al.), vol. 14, II (Mainz, 1973), 62-3, 85, 91, 221.

93 Parsifal: 'Dies alles - hab' ich nun geträumt?' (Act II, Parsifal).

94 Arthur Schopenhauer, Parerga and Paralipomena: Short Philosophical Essays, trans. E.F.J. Payne (Oxford, 1974), I, 239.

95 See, for instance, the opening discussion of Gianni Schicchi as a 'one-shot game' in Larry Samuelson and George J. Mailath, Repeated Games and Reputations: Long-run Relationships (Oxford, 2007), 1-2; and Illias Chrissochoidis and Steffen Huck, 'Elsa's Reason: On Beliefs and Motives in Wagner's Lohengrin', Cambridge Opera Journal 22 (2010), 65-91.

96 This is mentioned in the online review by IGN, 'Cryo's latest point-and-stare adventure game will want to make you cry' (20 July 1999), http://uk.ign.com/articles/1999/07/21/ring-thelegend-of-the-nibelungen (accessed 2 October 2013).

97 Though, equally, such an exploratory discourse can be read as an extension of Wolfgang Wagner's claim, documented only in conversation by film director Tony Palmer, that 'if my grandfather were alive today, he would undoubtedly be working in Hollywood. He would not have been able to resist the technical wizardry at his disposal.' Cited in Jeongwon Joe and Sander L. Gilman (eds.), Wagner \& Cinema (Bloomington and Indianapolis, 2010), x. 
While we might assume the domains of gaming and opera are cleanly insulated from each other by the difference between interactive and passive media, private and public environments, not to mention traditions of social indexing, this is not selfevident. Philip Auslander's celebrated thesis of a recursive loop between mediatised and live art would seem to capture the relationship-in-flux between simulcast and live acoustic opera that obtains today. It posits a symbiotic relationship, a spiral effect of mutual modification, where each form progressively mirrors its mirror:

Initially the mediatized form is modeled on the live form, but it eventually usurps the live form's position in the cultural economy. The live form then starts to replicate the mediatized form. This pattern is apparent in the historical relationship of theatre and television ... To the extent that live performances now emulate mediatized representations, they have become second-hand recreations of themselves as refracted through mediatization. ${ }^{98}$

We are long familiar with Adorno's complaint that 'the performance sounds like its own phonograph recording, ${ }^{99}$ But if the current regimen, applying Auslander's logic to the discourse of convergence, sees the simulcast authenticated by the 'reality' of the live performance, the reverse may be its fate as sound and sight become increasingly more stimulating than the 'real thing'. In that case, there would no longer be a difference in kind between the synthetic sounds of the Solti-emitting game console and the amplified upmixing of the cinema. Wagner's operas have entered into a digital economy in which authenticity is mobile and negotiable.

98 Philip Auslander, Liveness: Performance in a Mediatized Culture (London and New York, 1999), 158.

99 Theodor W. Adorno, The Culture Industry: Selected Essays on Mass Culture (Abingdon, 2001), 44. 